Eur J Pediatr (1986) 144: 445-450

\title{
Lacticacidaemia due to pyruvate dehydrogenase deficiency, with evidence of protein polymorphism in the $\alpha$-subunit of the enzyme
}

\author{
N. McKay ${ }^{1}$, R.Petrova-Benedict ${ }^{1}$, J. Thoene ${ }^{2}$, B. Bergen ${ }^{3}$, W. Wilson ${ }^{4}$, and B. Robinson ${ }^{1}$ \\ ${ }^{1}$ The Departments of Pediatrics and Biochemistry, University of Toronto and the Research Institute, Hospital for Sick Children, \\ Toronto, Ontario, Canada \\ ${ }^{2}$ Department of Pediatrics, University of Michigan, The C.S. Mott Childrens Hospital, Ann Arbor, Michigan, USA \\ ${ }^{3}$ Department of Pediatrics, University of Minnesota, Minneapolis \\ ${ }^{4}$ Department of Pediatrics, University of Virginia Medical Center, Charlottesville, Virginia, USA
}

\begin{abstract}
In three infants with neonatal lacticacidaemia, a deficiency in the $E_{1}$ (pyruvate dehydrogenase) component of the pyruvate dehydrogenase complex was demonstrated in skin fibroblast cultures. Residual activites of the pyruvate dehydrogenase complex in the activated state were $1.6 \%$, $3.9 \%$ and $18.8 \%$ of control values, respectively. Immunoprecipitation of extracts of cultures skin fibroblasts grown on ${ }^{35} \mathrm{~S}$-methionine with anti-pyruvate dehydrogenase complex antibody revealed an abnormality in the $\mathrm{E}_{1} \alpha$-component of these three patients when visualised after sodium dodecyl sulphate/polyacrylamide gel electrophoresis. This component appeared to have a slightly lower molecular weight than did this protein from control cell strains. Cell strains from other patients with a deficiency of the pyruvate dehydrogenase complex did not exhibit this defect. Three patients also showed dysmorphism and developmental abnormalities of the central nervous system.
\end{abstract}

Key words: Lacticacidaemia - Pyruvate dehydrogenase deficiency - Protein polymorphism - Developmental abnormalities

\section{Introduction}

The pyruvate dehydrogenase component $\left(E_{1}\right)$ carries out the first step, namely the oxidative decarboxylation of pyruvate in the reaction catalysed by the pyruvate dehydrogenase complex (PDHC) (Fig. 1). Reports of pyruvate dehydrogenase $\left(E_{1}\right)$ deficiency have described children either with ataxic episodes $[3-5,16]$ or with delayed motor and neurological development $[8,9,16,17,18]$. Other types of presentation resembled Leigh's encephalomyelopathy $[2,7,20]$ or were characterised by overwhelming lacticacidemia in the neonatal

Offprint requests to: Dr.B.H. Robinson, Ph.D., Research Institute, The Hospital for Sick Children, 555 University Avenue, Toronto, Ontario, Canada, M5G 1X8

Abbreviations: $\mathrm{PDHC}=$ pyruvate dehydrogenase complex; $\alpha-\mathrm{MEM}=\alpha$-minimal essential medium period $[9,16,19]$. We have described 18 patients with pyruvate dehydrogenase $\left(E_{1}\right)$ deficiency [14]. One major finding was facial dysmorphism or microcephaly in ten of them. Here we describe three cases of severe pyruvate dehydrogenase deficiency with evidence of protein polymorphism in the $E_{1} \alpha$ component.

\section{Materials and methods}

Cultures of skin fibroblasts. Skin fibroblast cultures from the patients and age-matched controls were grown in $\alpha$-minimal essential medium ( $\alpha$-MEM) supplemented with $10 \%$ fetal calf serum. $\alpha$-MEM contains $0.5 \mathrm{~m} M$ pyruvate as one of its growth consitituents.

Measurement of enzyme activities in cultures skin fibroblasts. Pyruvate dehydrogenase complex activity was measured in the native (unstimulated) and dichloroacetate activated state by the method of Sheu et al. [17] modified as suggested by Hyland and Leonard [10]. Pyruvate dehydrogenase $\left(E_{1}\right)$ was measured as described in [3]. Dihydrolipoyl transacetylase was measured by the method of Butterworth et al. [6] and dihydrolipoyl dehydrogenase by the method of Reed and Wilms [13]. Pyruvate carboxylase was measured by the method of Ballard and Hanson [1] and whole cell pyruvate oxidation as described [16].

Preparation of antisera. Rabbit antiserum against the purified pyruvate dehydrogenase complex isolated from pig heart [11] was prepared by an intramuscular injection followed by subcutaneous injections at weekly intervals. Pre-immune sera were collected and used as normal rabbit sera. Anti-pyruvate dehydrogenase complex antiserum was shown to inhibit pyruvate dehydrogenase complex activity in solution. It was also shown to immunoprecipitate the antigens $E_{1} \alpha, E_{1} \beta$ and the $E_{2}$ transacetylase when added to the pyruvate dehydrogenase complex.

Immunoprecipitation of ${ }^{35} S$-methionine labelled proteins. Cultured skin fibroblasts were grown to early confluence in 75 $\mathrm{cm}^{2}$ tissue culture flasks, one per cell strain per experiment. One day prior to radioactive labelling, the medium was re- 
moved from the flasks and replaced by $10 \mathrm{ml} \alpha$-MEM medium containing $10 \mu \mathrm{M}$ methionine. The following day the medium was replaced by $5 \mathrm{ml}$ of the same medium supplemented with $200 \mu \mathrm{Ci} / \mathrm{ml}$ of ${ }^{35} \mathrm{~S}$-methionine $(800-1,200 \mathrm{Ci} / \mathrm{mmol}$, Amersham, Arlington Heights, Ill.). The cells were incubated overnight and the radioactive medium was removed. Cells were extracted as described by Robinson et al. [15], first with Triton $\mathrm{X}-100$ and then with carbon tetrachloride. The resulting solution was subjected to an immunoprecipitation sequence with normal rabbit serum before immunoprecipitation with $10 \mu \mathrm{l}$ pyruvate dehydrogenase antibody in $1 \mathrm{ml}, 10 \mathrm{~m} M$ Tris$\mathrm{HCl} \mathrm{pH} 7.4,5 \mathrm{~m} M$ phenylmethyl sulphonylfluoride, $1 \mathrm{~m} M$ EDTA, $0,1 \%$ Triton X-100 and $1 \mu \mathrm{g} / \mathrm{ml}$ methionine. Immunoprecipitates were pelleted by the addition of IGsorb (The Enzyme Centre, Waltham, Mass.). The resulting pellets were taken up into a $1 \%$ sodium dodecyl sulphate solution for electrophoresis on $10 \%$ polyacrylamide slab gels.

${ }^{35} \mathrm{~S}$-labelled protein bands were visualised by fluorography with an exposure time of $72 \mathrm{~h}$.

\section{Case reports}

\section{Case 1}

A girl was born to a 26 -year-old $\mathrm{G}_{1} \mathrm{P}_{0}$ mother by Caesarian section at 42 weeks. The mother was treated by sulphasalazine for Crohn's disease. Apgar scores were 2 at $1 \mathrm{~min}$ and 3 at $5 \mathrm{~min}$. She required $45 \mathrm{~min}$ artificial ventilation. Initial metabolic acidosis was treated with sodium bicarbonate. Physical examination demonstrated an elfin face and a blowing systolic ejection murmur at the lower left sternal border. She had short arms and legs and bilateral simian creases. On day 5, slow tonic clonic seizures were noted and treated by phenobarbital. Throughout the first 40 days of life, she had episodic metabolic acidosis requiring intravenous bicarbonate administration. Blood lactic acid was $18.3 \mathrm{mM}$. At 30 days of age blood bicarbonate was $11 \mathrm{mEq} / 1$ despite dosage with $15 \mathrm{mEq}$ bicarbonate/day. She became increasingly lethargic and required ventilator support to avoid respiratory arrest.

At 40 days of age she was transferred for evaluation. Her weight was $2.94 \mathrm{~kg}$, and length $49 \mathrm{~cm}$. She was flaccid, pale and very hypotonic. She was breathing spontaneously but required a back-up ventilator rate of 15 . Her corneal reflexes were absent on the right, and intermittently present on the left. She had episodic seizures. A clinical diagnosis of valvular aortic stenosis was made.

On admission, serum sodium was $136 \mathrm{mEq} / \mathrm{l}$, potassium $2.4 \mathrm{mEq} / \mathrm{l}$, chloride $92 \mathrm{mEq} / \mathrm{l}$, bicarbonate $17 \mathrm{mEq} / \mathrm{l}$, glucose $118 \mathrm{mg} / \mathrm{dl}$, creatinine $2.6 \mathrm{mg} / \mathrm{dl}$, calcium $9.4 \mathrm{mg} / \mathrm{dl}$. Blood ammonia was $110 \mu M /$, lactate $18.6 \mathrm{~m} M / 1$ (normal $0.5-2.2$ ) and pyruvic acid $0.43 \mathrm{~m} M / 1$ (normal $<0.15 \mathrm{~m} M / \mathrm{l}$ ). Other organic acids were normal.

She required increasing amounts of bicarbonate $(44 \mathrm{mEq}$ on the third day) to maintain an acceptable blood $\mathrm{pH}$. Biotin $(10 \mathrm{mg})$ per oral-gastric tube did not cause clinical improvement. A CAT scan demonstrated extensive hydrocephalus and loss of brain tissue. An EEG revealed slow wave activity with intermittent spikes. On the third hospital day she was given $5 \mathrm{mg}$ thiamine per oral-gastric tube. During the next $24 \mathrm{~h}$, she became alkalotic with a $\mathrm{pH}$ of 7.62 and a bicarbonate level of $23 \mathrm{mEq} / \mathrm{l}$. Bicarbonate therapy was discontinued and over the next $24 \mathrm{~h}$ she maintained a normal $\mathrm{pH}$. However, she continued to require artificial ventilation. In view of the grossly abnormal CAT scan results, the patient was removed from the ventilator and expired on the 44th day of life. Autopsy showed hydrocephalus with polymicrogyria, widespread past and recent necrosis of the cerebral hemisphere and brain stem, ectopic olivary nuclei, absent corpus callosum, and aortic valvular stenosis.

\section{Case 2}

A girl was hospitalised at 6 days opf age following a series of brief apnoeic episodes at home. Her parents are unrelated. Her newborn nursery course and first days at home had been unremarkable. Physical examination revealed a lethargic, hypotonic infant with periods of apnoea accompanied by bradycardia, lasting $20-40 \mathrm{~s}$; both responded to bagging. Focal seizure activity (twitching of the right hand and foot) was noted. Initial laboratory studies included normal serum electrolytes, T4, TSH, blood count, glucose, calcium, magnesium and arterial blood gas determinations; serum transaminases and blood ammonia were at slightly elevated levels. After finding elevated urine and plasma alanine levels, markedly increased blood lactate $(8.4 \mathrm{mmol} / 1)$ and pyruvate $(0.66 \mathrm{mmol} / \mathrm{l})$ were documented. Urinary organic acid analysis showed elevations of lactate, pyruvate, and alpha-ketoglutarate. Ultrasound examination of the cranium showed mild dilation of the lateral and third ventricles. Thiamine triphosphate synthetase inhibitor was absent from urine (courtesy of Dr. Jack Cooper, Yale University). An EEG at the age of 7 months showed a multifocal spike pattern.

A brief trial with oral lipoic acid and thiamine was not followed by clinical or biochemical improvement. At the age of 22 months, the patient shows marked growth retardation and developmental delay; her developmental age is 5-8 months with cognitive skills being somewhat higher than motor skills. She has an unusual facial appearance with prominence of the frontal region, bitemporal narrowing, a short, upturned nose, full cheeks, and a wide mouth. There is hypotonia and slight hyperflexia. Although she has had no further episodes of apnoea, she continues to have elevated levels of blood lactate $(5.7-8.5 \mathrm{mmol} / \mathrm{l})$ and pyruvate $(0.52 \mathrm{mmol} / \mathrm{l})$.

\section{Case 3}

This girl was the first-born of unrelated Caucasian parents. The 32-year-old, gravida 2, para 1 mother entered spontaneous labour and breech delivery at term following an uneventful pregnancy. The amniotic fluid was meconium-stained. The $2510 \mathrm{~g}$ infant had an Apgar score of 2 at 1 min. Immediate bagging and intubation were required because of inadequate respiratory effort. By $2 \mathrm{~h}$ of age, oxygenation was adequate with spontaneous ventilation in room air.

On physical examination the patient was found to be lethargic, hypotonic, areflexic and inactive. Respiration was rapid. Eye movements were minimal. Her head circumference was $34.2 \mathrm{~cm}$ (60th percentile) and crown-heel length $48 \mathrm{~cm}$ (30th percentile). The fontanelle was soft. There was no clinical or laboratory evidence of cardiopulmonary disease. There was micrognathia, low set ears with normal pinnae, narrow palpebral fissures, short neck with redundant skin, thick, "straight" shocky hair, genua valga, joint contractures at the elbows, shoulders and hips and pes cavus with hammer toes. The cry was weak and root, suck and gag reflexes were absent. 
Table 1. Results of enzyme analysis

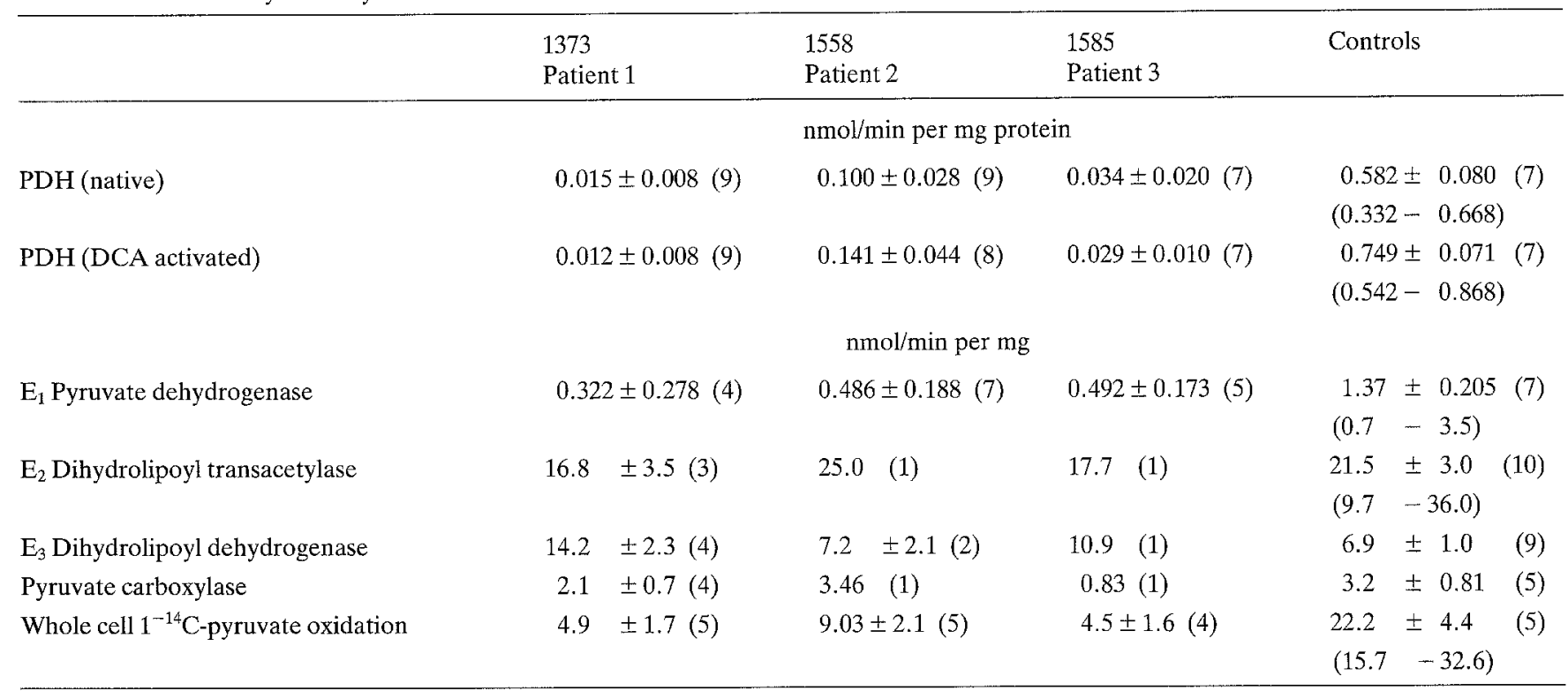

Values are mean \pm S.E. (number of determinations in parenthesis)

Values are given for controls performed on the same day as the cell strain to be tested together with the range of those values

$\mathrm{DCA}=$ dichloroacetate

She did not follow a light. Her head lag was marked, and there was no trunk or leg supporting response. The Moro reflex consisted of minimal arm extension. Deep tendon reflexes were absent. There was no hepatosplenomegaly.

There was no clinical or biochemical change following the oral administration of thiamine $(1 \mathrm{~g} /$ day $)$ over 3 months.

The initial investigation revealed a persistent metabolic acidosis with an elevated anion gap $\left(\mathrm{pH} 7.35, \mathrm{PCO}_{2} 29\right.$, bicarbonate $16 \mathrm{mEq} / \mathrm{l}$, sodium $138 \mathrm{mEq} / \mathrm{l}$, potassium $4.0 \mathrm{mEq} / 1$, chloride $106 \mathrm{mEq} / \mathrm{l}$. The blood lactic acid concentration was $21 \mathrm{mmol} / 1$ and pyruvic acid concentration $0.38 \mathrm{mmol} / 1$. Initial serum ammonia was $176 \mu \mathrm{mol} / \mathrm{l}$ (normal less than 110), but this fell to $85 \mu \mathrm{mol} / \mathrm{l}$ within 1 day. Serum amino acids, glucose, electrolytes, SGOT, $\mathrm{T}_{4}$ and TSH were normal. Chromosomes were normal. There was no inhibitor of thiamine triphosphate synthetase in the urine. Marked elevation of urinary lactic acid and alpha-ketoglutaric acid was found with a slight elevation of malic acid and fumaric acid. Muscle biopsy showed occasional enlarged type I fibres, but no "ragged-red" fibres were present. Electron microscopy of muscle gave normal results. A CT scan on the first day showed moderate ventricular enlargement with extensive hypodensity of white matter.

\section{Results and diskussion}

\section{Activities of the enzymes of pyruvate metabolism}

The activity of the pyruvate dehydrogenase complex was measured in cultured skin fibroblasts in the native state and after activation with dichloroacetate (Table 1). The activities of the enzyme complex in the native state were $2.6 \%, 5.8 \%$ and $17.2 \%$ of the control values, respectively while in the activated state the values were $1.6 \%, 3.9 \%$ and $18.8 \%$, respectively. There was thus, no significant activation with dichloroacetate. The assay system of Sheu et al. [17] in our hands only gives a $50 \%$ increase in activity of the pyruvate dehydrogenase complex after activation with dichloroacetate. This we believe is due to the fact that our cells are cultured in $\alpha$-MEM, a pyruvate-containing culture medium. Assay of the three catalytic components of the complex revealed decreased activity of pyruvate dehydrogenase $\left(E_{1}\right)$, rather than of dihydrolipoyl transacetylase $\left(E_{2}\right)$ or of dihydrolipoyl dehydrogenase $\left(E_{3}\right)$. The higher residual activities of the pyruvate dehydrogenase component, as compared to those of the pyruvate dehydrogenase complex, lead us to suggest that the former assay measures some other enzyme activity that decarboxylates pyruvate or that the defects in $E_{1}$ activity are more deleterious to the activity of the whole complex than to the

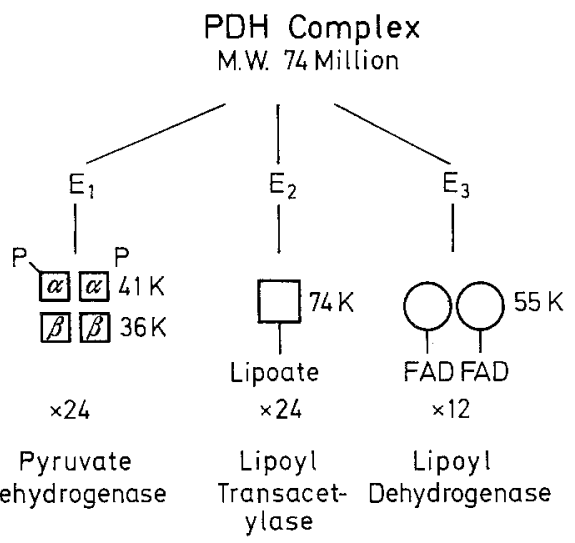

Fig. 1. Composition of the pyruvate dehydrogenase complex in bovine kidney (after Reed [12]). The total complex has a molecular weight of $7.4 \times 10^{6}$ daltons, being made up of three catalytic components. The $E_{1}$, dehydrogenase is made up of $24 \alpha_{2} \beta_{2}$ tetramers, the $\alpha$-subunit of which can be phosphorylated and dephosphorylated. The $E_{2}$ lipoyl transacetylase is made up of 24 monomers of 52 kilodaltons, which appear to be 74 kilodaltons by polyacrylamide gel electrophoresis and have covalently attached lipoic acid. The $\mathrm{E}_{3}$ lipoyl dehydrogenase is made up of 12 dimers of 55 kilodaltons which have tight binding sites for flavin adenine dinucleotide (FAD) 
isolated $\mathrm{E}_{1}$ activity, measured with artificial electron acceptors $\left(\mathrm{Fe}\left(\mathrm{CN}_{6}\right)^{3-}\right)$. The activity of PDHC correlates well with the rate of $1{ }^{14} \mathrm{C}$-pyruvate oxidation in whole cells. It might be postulated because of the lack of activation seen in the pyruvate dehydrogenase complex of these patients that the low activity of the complex was due to pyruvate dehydrogenase phosphatase deficiency. Though we cannot eliminate this possibility totally, it is unlikely because of the polymorphism in the $E_{1} \alpha$ pyruvate dehydrogenase component demonstrated in the following section.

\section{Immunoprecipitation of the pynavate dehydrogenase complex}

Skin fibroblasts were cultured in a medium containing ${ }^{35} \mathrm{~S}$ methionine to label newly synthesised proteins and the $\mathbf{C C l}_{4}$ cell extracts incubated with anti-pyruvate dehydrogenase antiserum. The immunoprecipitates formed both with this antiserum and control pre-immune serum were electrophoresed on $12.5 \%$ polyacrylamide/sodium dodecyl sulphate gels and the resulting labelled protein distribution was examined by fluorography (Fig. 1). The pattern with anti-pyruvate dehydrogenase antiserum revealed the presence of dark bands corresponding to proteins at $74 \mathrm{~K}, 43 \mathrm{~K}$, and $36 \mathrm{~K}$. These correspond to the positions of $\mathrm{E}_{2}, \mathrm{E}_{1} \alpha$ and $\mathrm{E}_{1} \beta$ respectively (Fig. 2), all members of the pyruvate dehydrogenase complex except that the $E_{1} \alpha$ component of bovine kidney is slightly lower at $41 \mathrm{~K}$ [12]. The antibody was not found to have activity towards $\mathrm{E}_{3}$ either by this technique or by Ouchterlony diffusion. Control serum brings down a major band at $43 \mathrm{~K}$ which can be reduced in intensity by prior pre-incubation and immunoprecipitation with a monoclonal antibody against actin.

Two cell lines (1108 and 1118) with PDHC deficiency activities similar to 1558 (from patient 2) show the same fluorographic pattern as the control cell line 411 (Fig. 1). However, the deficient cell line 1373 (from patient 1) shows a split double band corresponding to $\mathrm{E}_{1} \alpha$ : One of the bands is in the same position as actin $\left(43 \mathrm{~K}\right.$ ) or the control $\mathrm{E}_{1} \alpha$ band while the other appears to be somewhat smaller $(41 \mathrm{~K})$. When a monoclonal antibody against actin was used to remove actin, 1373

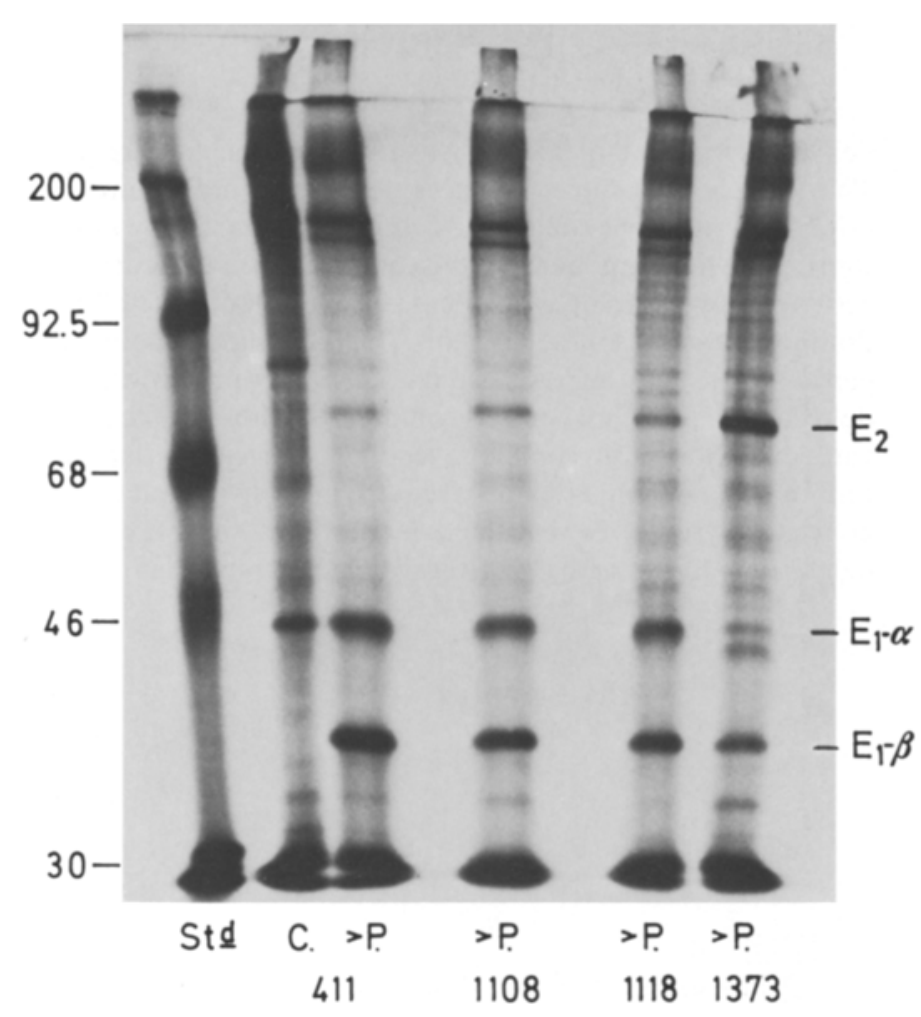

Fig.2. Protein polymorphism in pyruvate dehydrogenase-deficient cell lines. Proteins were immunoprecipitated from ${ }^{35} \mathrm{~S}$-methionine labelled cultured skin fibroblast extracts with either control serum $(C)$ or anti-pyruvate dehydrogenase antiserum $(P)$. The immunoprecipitates were run on standard sodium dodecyl sulphate $/ 12.5 \%$ polyacrylamide electrophoretic gel and the pattern of radioactivity revealed by fluorography. Lanes from left to right are lane 1, protein standards (myosin $\mathrm{M}_{\mathrm{r}}=200000$, phosphorylase $\mathrm{b}, \mathrm{M}_{\mathrm{r}}=92500$, albumin $\mathrm{M}_{\mathrm{r}}=$ 68000 , ovalbumin $M_{\mathrm{r}}=46000$, carbonic anhydrase $M_{\mathrm{r}}=30000$ ); lane 2, control cell line 411 with control serum; lane 3 control cell line 411 with anti-PDH anti-serum, lane 4, PDH-deficient cell line 1108 with anti-PDH antiserum; lane 5, PDH-deficient cell line 1118 with anti-PDH antiserum; lane 6, PDH-deficient cell line 1373 with antiPDH antiserum. $\mathrm{E}_{1} \alpha, \mathrm{E}_{1} \beta$ indicate the positions of the $\alpha$ and $\beta$ subunits of the $E_{1}$ pyruvate dehydrogenase while $E_{2}$ indicates the position of the dihydrolipoyl transacetylase subunit from the PDH complex

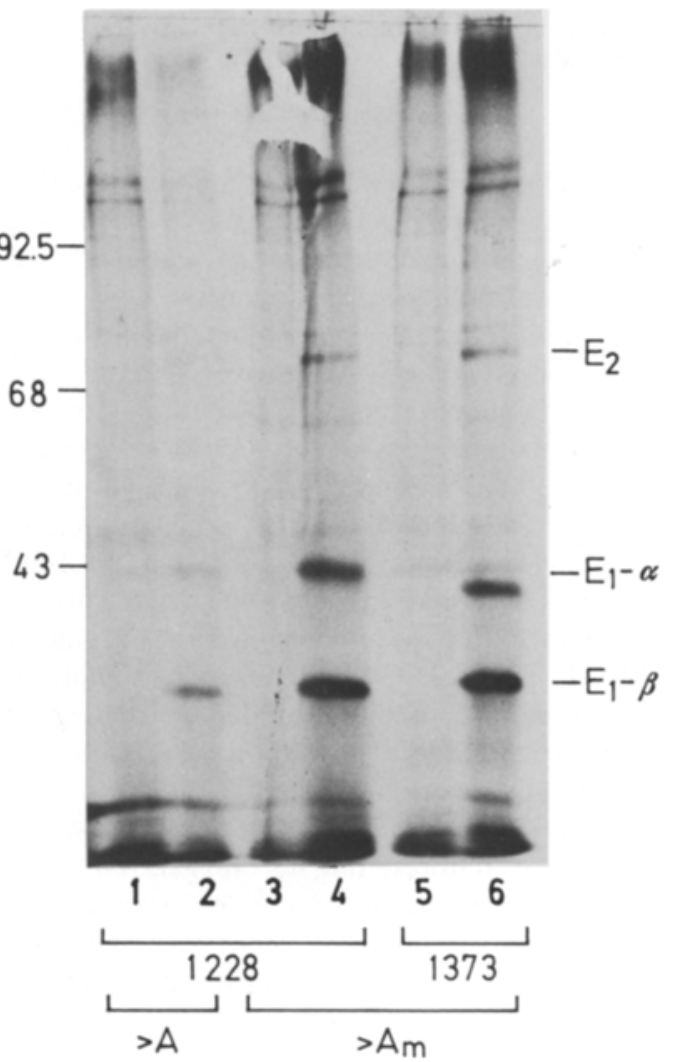

Fig.3. Inmunoprecipitated ${ }^{35} \mathrm{~S}$-labelled proteins obtained with antipyruvate dehydrogenase antiserum after treatment of the extracts with anti-actin antiserum. Experiments were performed as described for Fig. 2 except that two samples were pre-extracted with $10 \mu \mathrm{l}$ antiactin (anti-A) (Miles-monospecific) and four samples with $10 \mu \mathrm{l}$ antiactin antiserum (anti-Am) (Amersham monoclonal). Lane 1, control cell line 1228 pre-immunoprecipitated by anti-A then by control serum; lane 2, control cell strain 1228 pre-immunoprecipitated by anti-A followed by anti-PDH antiserum; lane 3, control cell strain 1228 pre-immunoprecipitated with anti-Am followed by control serum; lane 4 control cell strain 1228 pre-immunoprecipitated with anti-Am followed by anti-PDH antiserum; lane 5, PDH-deficient cell line 1373 pre-immunoprecipitated with anti-Am followed by control serum; lane 6, PDH deficient cell line 1373 pre-immunoprecipitated with anti-Am followed by anti-PDH antiserum 


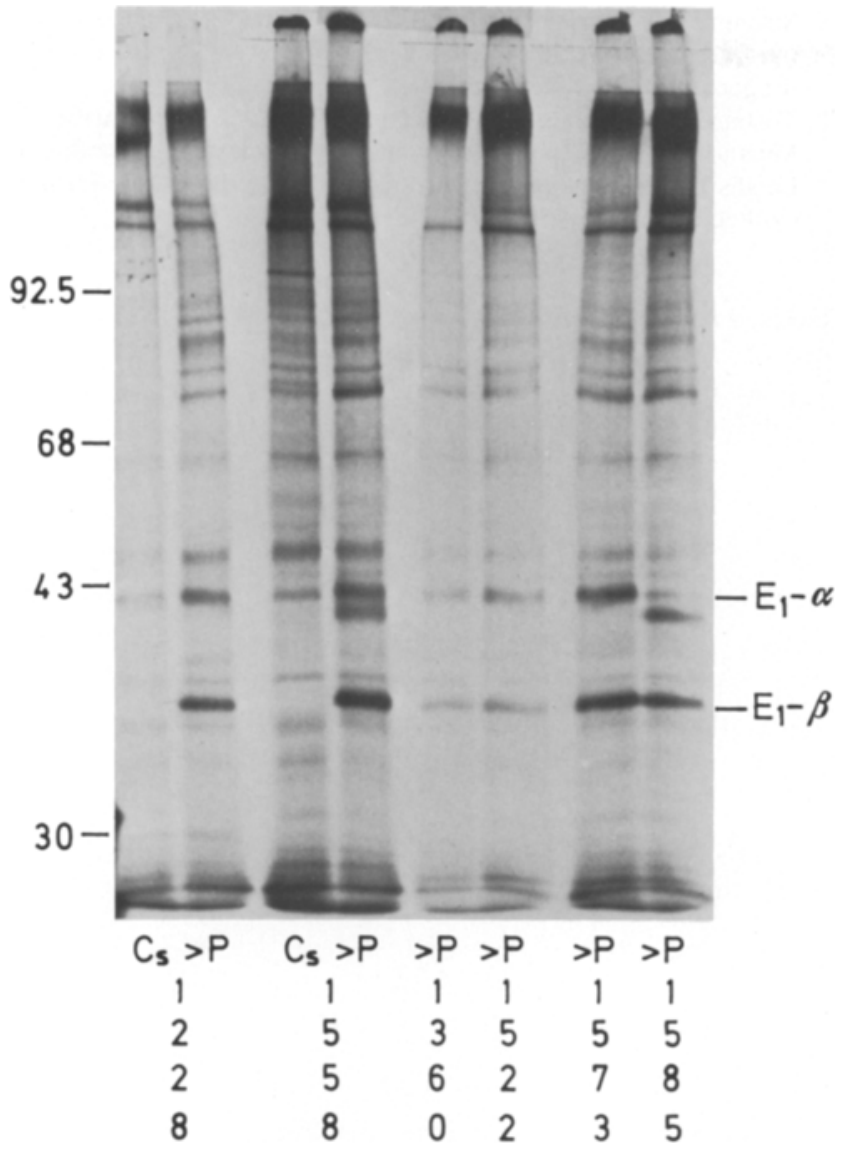

Fig.4. Protein polymorphism in pyruvate dehydrogenase deficient cell lines. Proteins were immunoprecipitated from ${ }^{35} \mathrm{~S}$-methionine labelled cultured skin fibroblast extracts with either control serum $\left(\mathrm{C}_{S}\right)$ or anti-pyruvate dehydrogenase antiserum $(P)$. The immunoprecipitates were run on standard sodium dodecyl sulphate $12.5 \%$ polyacrylamide electrophoretic gel and the pattern of radioactivity revealed by fluorography. Lanes from left to right are: lane 1, control cell line 1228 with control serum; lane 2, control cell strain 1228 with anti-PDH antiserum; lane 3, PDH-deficient cell strain 1558 with control serum; lane 4, 1558 with anti-PDH antiserum; lane 5, 6, 7, 8, PDH-deficient cell strains $1360,1552,1573$ and 1585 with anti-pyruvate dehydrogenase antiserum. $E_{1} \alpha$ and $E_{1} \beta$ indicate the position of $\alpha$ and $\beta$ subunits of the $\mathrm{E}_{1}$ pyruvate dehydrogenase component

showed only a predominant $41 \mathrm{~K}$ band (Fig. 3). When monospecific antibody to actin was used it did not appear to remove the contaminating actin band as effectively with preservation of the PDH-specific antigens. The two other PDHC-deficient cell lines 1585 (patient 3) and 1558 (patient 2) showed the double band demonstrated in 1373, which was not seen in ten other PDHC-deficient cell lines tested nor in any control cell line tested (Fig. 4).

Despite the fact that these three children had the same basic enzyme defect, they showed some differences. Patient 2 had facial dysmorphism with microcephaly, patient 3 had less pronounced features of dysmorphism and patient 1 had a normal appearance. Two of the children had increased $\alpha$-ketoglutarate excretion in the urine. All three had lacticacidaemia, difficult to control and (patient 1) died in the neonatal period. In this child, the brain was already morphologically affected at birth, showing agenesis of the corpus callosum and ectopic olivary nuclei. The brain stem showed cystic lesions at autopsy. A CT scan revealed hypodense white matter in patient 3 with moderate ventricular enlargement, while patient 2 had microcephaly ands ventricular dilation noted by ultrasound.

Pyruvate dehydrogenase deficiency appears to effect the development of the head so that either malformation of the brain, microcephaly and/or facial dysmorphy may occur. Subsequently, cystic lesions may develop in the white and gray matter, especially in the basal ganglia. Since the brain stem is perhaps the most metabolically active area, areas of necrosis indicate that cell death is occurring. This could be due either to lack of intracellular ATP or to locally high concentrations of lactic acid secondary to the enzymatic deficiency.

In summary, we present evidence for protein polymorphism of the $\mathrm{E}_{1}$ component in three patients with $\mathrm{PDH}-\mathrm{E}_{1}$ deficiency.

Acknowledgement. BHR thanks the National Foundation March of Dimes for financial support.

\section{References}

1. Ballard FJ, Hanson RN (1967) Phosphoenolpyruvate carboxykinase and pyruvate carboxylase in developing rat liver. Biochem J 104: 866-871

2. Blass JP (1983) Inborn errors of pyruvate metabolism. In: Stanbury JB, Wyngaarden JB, Frederickson DS, Goldstein JL, Brown MS (eds) The metabolic basis of inherited disease, 5th edn. McGraw Hill, New York, pp 193-203

3. Blass JP, Avigen J, Uhlendorf BW (1970) A defect in pyruvate decarboxylase in a child with an intermittent movement disorder. J Clin Invest 49:423-432

4. Blass JP, Kark RAP, Engel WK (1971) Clinical studies of a patient with pyruvate decarboxylase deficiency. Arch Neurol 25: 449-460

5. Blass JP, Lonsdale D, Uhlendorf BW, Ham E (1971) Intermittent ataxia with pyruvate decarboxylase activity. Lancet $1: 1302$

6. Butterworth PJ, Tsa CS, Eley MH, Roche TE, Reed LJ (1975) Kinetic study of dihydrolipoyl transacetylase from bovine kidney. J Biol Chem 250: 1921-1925

7. Devivo DC, Haymond MW, Obert KA, Nelson JS, Pagliara AS (1979) Defective activation of the pyruvate dehydrogenase complex in subacute necrotising encephalomyelopathy (Leigh Disease). Ann Neurol 6:483-494

8. Farmer TW, Veath L, Miller AL, O'Brien J, Rosenberg RN (1973) Pyruvate decarboxylase deficiency in a patient with subacute necrotising encephalomyelopathy. Neurology 23:429

9. Farrel DF, Clark AF, Scott CR, Weenberg RP (1975) Absence of pyruvate decarboxylase activity in man. A cause of congenital lacticacidosis. Science 187: 1082-1084

10. Hyland K, Leonard JV (1983) Revised assays for the investigation of congenital lactic acidosis using ${ }^{14} \mathrm{C}$-ketoacids eliminating problems associated with spontaneous decarboxylation. Clin Chim Acta 133:177-187

11. Linn TE, Pettit FH, Hucho F, Reed LJ (1969) Keto acid dehydrogenase complexes. XI. Comparative studies of the regulatory properties of the pyruvate dehydrogenase complexes from kidney, heart and liver mitochondria. Proc Natl Acad Sci USA 64:227234

12. Reed LJ (1981) Regulation of mammalian pyruvate dehydrogenase complex by a phosphorylation-dephosphorylation cycle. Curr Top Cell Regul 18:95-106

13. Reed LJ, Wilms CR (1966) Purification and resolution of the pyruvate dehydrogenase complex. Methods Enzymol 9:247-277

14. Robinson BH, Sherwood WG (1985 in press) Lactic acidemia, the prevalence of pyruvate decarboxylase deficiency. J Inherited Metab Dis

15. Robinson BH, Oei J, Sherwood WG, Applegarth D, Wong L, Haworth J, Goodyer P, Case R, Zaleski LA (1984) The molecular basis for the two different clinical presentations of classical pyruvate carboxylase deficiency. Am Hum Gen 36:283-294 
16. Robinson BH, Taylor J, Sherwood WG (1980) The genetic heterogeneity of lactic acidosis: occurrence of recognisable inborn errors of metabolism in a pediatric population with lacticacidosis. Pediatr Res 14:956-962

17. Sheu KFR, Hu CWC, Utter MF (1981) Pyruvate dehydrogenase complex activity in normal and deficient fibroblasts. J Clin Invest $67: 1463-1471$

18. Sorbi S, Blass JP (1981) Spectrophotometric measurement of pyruvate dehydrogenase complex activity in cultured human fibroblasts. J Biochem Biophys Methods 5:169-176
19. Stromme JH, Borud O, Moe PJ (1976) Fatal lactic acidosis in a newborn attributable to a congenital defect of pyruvate dehydrogenase. Pediatr Res 10:60-66

20. Toshimo K, Kuroda Y, Hashimoto T, Ho M, Watanabe T, Miyano M, Li K (1982) Enzymologic studies and therapy of Leighs Disease associated with pyruvate decarboxylase deficiency. Pediatr Res 16:430-435

Received August 15, 1984 / Accepted May 28, 1985

SYNDROMES are the signpost and compass and map which direct us through the crowded twisting streets, the oceans, and the jungles of medical experience. They are not points of arrival, nor things. They are not immutable, and are always to be reviewed critically. A full understanding of the logical system implied by the syndrome should enable us to guide our patient with confidence and wisdom; should suggest and direct our researches; and should refresh our sense of gratidue to our medical forefathers.

William Gooddy, Lancet 1:1, 1961 